Report No. 102014-TR

\title{
GENDER EARNING GAP IN THE FORMAL LABOR MARKET IN TURKEY
}




\title{
GENDER EARNINGS GAP IN THE FORMAL LABOR MARKET IN TURKEY
}

\author{
Tolga Cebeci'
}

\footnotetext{
${ }^{1}$ The World Bank, tcebeci@worldbank.org. I thank very much to Mediha Agar, Ana Maria Munoz Boudet, Carolina Sanchez-Paramo and Cagla Okten for providing very useful comments on the draft of this paper. All remaining errors are mine. The findings expressed in this paper are those of the author and do not necessarily represent the views of the World Bank.
} 
(C) 2015 International Bank for Reconstruction and Development / The World Bank

1818 H Street NW

Washington DC 20433

Telephone: 202-473-1000

Internet: www.worldbank.org

\section{Standard Disclaimer:}

This volume is a product of the staff of the International Bank for Reconstruction and Development/The World Bank, and it has been produced as part of the "Increasing Women's Acccess to Economic Opportunities in Turkey" Project (2012-2017) which is funded by the Swedish International Development Cooperation Agency (SIDA) and implemented by the Ministry of Family and Social Policies (MoFSP) of the Republic of Turkey and the World Bank. The findings, interpretations, and conclusions expressed in this paper do not necessarily reflect the views of MoFSP, SIDA, the Executive Directors of The World Bank or the governments they represent. The World Bank does not guarantee the accuracy of the data included in this work. The boundaries, colors, denominations, and other information shown on any map in this work do not imply any judgment on the part of The World Bank concerning the legal status of any territory or the endorsement or acceptance of such boundaries.

\section{Copyright Statement:}

The material in this publication is copyrighted. Copying and/or transmitting portions or all of this work without permission may be a violation of applicable law. The International Bank for Reconstruction and Development/ The World Bank and the Ministry of Family and Social Policies (MoFSP) of the Republic of Turkey encourages dissemination of its work and will normally grant permission to reproduce portions of the work promptly. 


\section{TABLE OF CONTENTS}

\section{INTRODUCTION}

1.1 CONTEXT AND SUMMARY FINDINGS

1.2 LITERATURE

5

1.3 DATA AND Methodology

2. GENDER GAP IN EMPLOYMENT BY EMPLOYEE CHARACTERISTICS

2.1 OVerall Gender GaP in EMPLOYMent

2.2 GAP BY SECTOR AND OCCUPATION

2.3 GAP BY EDUCATIONAL ATTAINMENT

4. GENDER GAP IN EARNINGS: PRELIMINARY ANALYSIS

4.1 COMPARISON OF HOURS WORKED

4.2 OVERALL GAP IN EARNINGS

4.3 GAP BY SECTOR AND OCCUPATION

20

4.4 GAP BY EDUCATIONAL ATTAINMENT

21

4.5 GAP BY YEARS OF EXPERIENCE

\section{REFERENCES}

\section{APPENDIX}

A3.1 GAP BY FIRM SIZE

A3.2 GAP BY FIRM LOCATION

A4.3 DistRIBUTION OF EARNINGS

A5 Gender Gap In EARNINGS: Regression ANALYSIS 


\section{INTRODUCTION}

\subsection{CONTEXT AND SUMMARY FINDINGS}

1. Gender disparities in Turkey remain considerable despite Turkish government's recent public policy initiatives ${ }^{2}$ aimed at increasing gender equity in Turkey. Overall gender equity ranking of Turkey in the Gender Gap 2012 Report (Hausmann et al.) is 124 out of 135 countries. Interestingly, Turkey's performance varies in different dimensions of gender equity. On the one hand, its gender equity score is higher than 0.9 in health and educational attainment (score 1 indicates full equity). On the other hand, its score is 0.41 in economic and 0.09 in political participation. Moreover, its performance in economic participation in 2012 is lower than its 2005 level.

2. Gender equity is identified as a key area in the 2012-2015 Country Partnership Strategy of the World Bank Group (WBG) in Turkey. One of the projects initiated to move WBG's gender agenda in Turkey further is the "Technical Assistance Project on Promoting Gender Equity in Labor Markets and Entrepreneurship". Using novel datasets, this study aims to contribute to the project through providing a better understanding of different dimensions of the gender gap in employment and particularly earnings.

3. Key findings of this paper are as follows:

i) The gap between men and women in participation emerges with the early exit of women, particularly those low educated, after marriage. Partly due to that, average female employee is more educated than the average male employee. This provides a positive premium on female earnings over male earnings.

ii) Partly due to exit of low educated women after marriage, female employees, on average, have less work experience than male employees. This contributes significantly to the earnings gap between male and female employees.

iii) Compared to men, women work in higher paying sectors, sub-sectors and firms within sub-sectors. Yet, women earn less than the men working in the same firm.

iv) Female employees are more concentrated in larger firms especially in the East and the North regions of the country.

v) Once all observable characteristics are taken into account, it is hard to argue that earnings discrimination against women in the formal labor market of Turkey is large. However, very low female labor supply might be the factor preventing a sizeable earnings discrimination in the formal labor market.

\footnotetext{
${ }^{2}$ For example, Promoting Women's Employment Operation of Labor Agency, the First Step Credit of Halkbank and Turkish Grameen Microcredit Programme. See Goksen et al. (2013) for a review of female oriented employment policies in Turkey.
} 


\subsection{LITERATURE}

4. Earnings and particularly wage gap between women and men has been a popular topic at the interplay between labor and gender economics. Although most studies report significant gender gap in earnings, the literature has been inconclusive in many aspects so far. Not only the measured magnitude of earnings gap but also the portion of the gap assigned to gender discrimination differs considerably within the group of studies that detect earnings gap. Moreover, a diverse set of reasons are cited as the source of the gap in different studies. Along with the variety of methodologies followed, dissimilarities in the coverage and the content of datasets used as well as country specific economic and social characteristics play a role in getting diverse results across studies.

5. Using data for 22 countries over 1985-1994, Blau and Kahn (2001) document that gender gap in earnings is low in Eastern Europe but very high in industrialized countries. They specifically report that men earn as low as $14 \%$ and as high as $85 \%$ more than women in Slovenia and Japan, respectively. According to International Labor Organization (2001), gender earnings disparities are lowest in North Korea (54\%) and highest in Swaziland (106\%). Besides, OECD countries do not have a significantly lower wage gap than other countries with similar development levels. Hertz et al. (2008) find a $25 \%$ average earnings gap in favor of men for 14 developing countries from all parts of the world. Hoyos and Nopo (2010) measure that earnings of women were $16.3 \%$ and $8.8 \%$ lower than the men of similar characteristics in Latin America in 1992 and 2007, respectively. In a cross-country study, Nopo et al. (2011) find that women earn $8 \%-48 \%$ less than the men with same characteristics. As for Turkey, using household expenditure surveys, Tansel (2004) detect a large wage gap in the private sector in favor of men.

6. Regarding the sources of earnings gap, a combination of economic (e.g. level of informality, occupational/sectoral segregation), personal (e.g. age, education, experience) and social (e.g. traditional roles assigned to women) factors are referred to be decisive. Pastore (2010) report that most of the earnings gap in Mongolia is due to different treatment of same characteristics of men and women by the market. Hoyos and Nopo (2010) posit that differences in job tenure explain a substantial part of earnings gaps. Using European Structure of Earnings Survey, Simon (2007) reports for nine industrialized and transition countries that female segregation into low-wage workplaces is the main contributor to the earnings gap. Similarly, Tzannatos (1999) cite sectoral segregation of women to lower wage sectors as a main source of earnings gap. On the other hand, Atal et al. (2009) discredit the role of occupational segregation by documenting that job related characteristics (e.g. occupation, size of firm) account for only a little share of earnings gap in Latin America. Finally, Blau and Kahn (2001) claim that earnings gap is lower if female net supply is lower in a country. ${ }^{3}$

\footnotetext{
${ }^{3}$ For a detailed review of the earnings gap literature see Nopo et al. (2011).
} 


\subsection{Data AND Methodology}

7. To measure the existence and magnitude of gender earnings gap in the formal labor market in Turkey, this paper make use of Earning Surveys (ES) conducted by the Turkish Statistics Institute (Turkstat) in 2006 and 2010. ES include a rich set of information about the earnings structure and characteristics of employees working in a sample of around 18,000 establishments in 2006 and 14,000 in 2010, covering all sectors except agriculture. All employees who work for wage in establishments (local units) of enterprises with at least 10 employees are covered in the ES. Gender, age, educational attainment, occupation, duration of employment in the firm, type of employment (part vs. full time; permanent vs. temporary), hours worked by type (regular vs. overtime), type of earnings (basic wage, over time payments etc.) of employees and sector of establishments are covered by the ES. Except for those whose source is explicitly stated, all numbers, tables and figures in this study are based on ES.

8. ES has some significant advantages over surveys based on household data, specifically Household Labor Force Surveys (LFS): First, ES can be considered more reliable as it is based on firm records. Second, it allows comparing of men and women working in the same firm through within-firm analysis. This is important because firms in a sector are usually quite heterogeneous in many aspects including size, productivity and profitability. Not taking into account the firm heterogeneity might result in misleading conclusions on the sources of earnings gap. On the other hand, ES covers only formal employment in formal firms. Therefore, all findings in this study adhere only to formal labor market.

9. The second set of dataset used in the study is the annual Industry and Services Surveys (ISS) of the Turkstat. ISS covers all firms with at least 20 employees and a large sample for those employing less than 20 employees. Number of employees by gender is the only gender specific variable in the ISS. The third dataset, Demographic and Household Surveys (DHS) of ICF International, is used to monitor the effect of marriage on female employment in the Second Section. DHS data for Turkey belongs to 2003-2004 and includes information of more than 8,000 married women of 15-50 years old. Finally, several figures of this study make use of LFS conducted by Turkstat.

10. As for the methodology, a pooled regression model is applied with a dummy for being female. Usually, a specification is re-run to undertake various within-group estimations by adding a combination of dummies representing different characteristics. This method has been used by, for example, Neal and Johnson (1996) to measure racial wage gaps and Fryer and Levitt (2004) to measure racial test score gaps. It is frequent in the literature to measure gender gap by decomposing earnings gaps into explained and unexplained parts. Most famous decompositions are those introduced by Oaxaca (1973) and Blinder (1973), known as O-B decomposition. Although it is straightforward to undertake it, a potential problem with O-B decomposition is that it is not unique in defining explained and unexplained components, as also acknowledged by the authors. In fact, Elder et al. (2010) 
document empirically that different alternatives, which are equally preferable from a theoretical perspective, of O-B decomposition yield very different gap estimations. They further show that using a female dummy in an OLS regression is an attractive approach for obtaining a measure of the unexplained earnings gap.

11. Section Two and Three of this paper are dedicated to the investigation of gender gap in labor market participation. These two sections serve as an introduction to the earnings gap analysis by documenting employee characteristics in Turkey. In Section Two, female participation by various employee characteristics (education, age, occupation, employment type) and sector are studied. Third section addresses the association between female share in the total employment of firms and firm size and location.

12. Section Four and Section Five analyze the gender gap in earnings. Whilst Section Four provides a descriptive and preliminary insight on the associations between earnings gap and employee characteristics, Section Five uses econometric techniques to identify individual associations between the earnings gap and each employee characteristics. Section Six recommends policies to decrease gender gap in earnings and participation.

\section{GENDER GAP IN EMPLOYMENT BY EMPLOYEE CHARACTERISTICS}

\subsection{OVERALl Gender GAP In EMPLOYMENT}

13. Although improved slightly, formal female employment lags far behind male employment in Turkey. According to ES, $23.1 \%$ of 5.98 million and $24.7 \%$ of 6.17 million formally employed in industry and services were women in 2006 and 2010, respectively 4 .

14. The reason for low female employment is low female LFP rather than high unemployment rate among women. Female LFP in Turkey is still below $30 \%$ in spite of some improvements after 2005 and in sharp contrast to the above 70\% male LFP. On female LFP, Turkey is separated from economically comparable countries in East Europe and Latin America and classified in the lowest category together with most Middle Eastern, North African and South Asian countries (World Bank, 2012).

\footnotetext{
${ }^{4}$ According to LFS, share of female in non-agricultural $10+$ firms was $21.5 \%$ and $23.2 \%$ of total formal employment in these firms in 2006 and 2010, respectively. During the period, observations in the ES represent $45 \%$ of non-agricultural total female and $44 \%$ of non-agricultural total male employment measured by the LFS. Exclusion of firms with less than 10 employees and exclusion of informal employment from the ES account for this difference.
} 
Figure 2.1: Labor Force Participation and Unemployment Rates

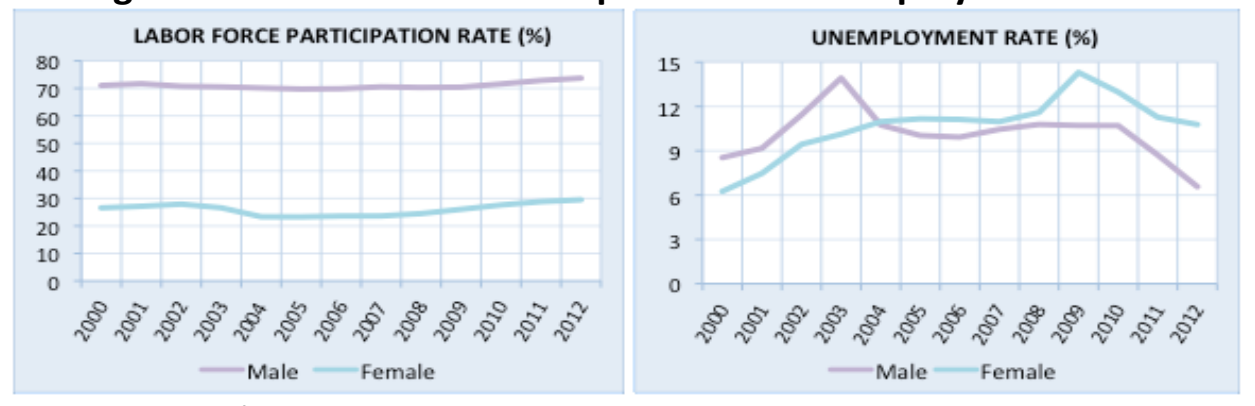

Source: LFS, Turkstat

15. Incidence of part-time employment (PTE) in the formal employment is still negligible compared to PTE in the informal employment ${ }^{5}$. Share of part-time employed female and male in total formal employment doubled, respectively, to $2 \%$ and $1.1 \%$ over $2006-2010$. On the other hand, once formal and informal employment considered together, PTE accounted for around $7 \%$ of total male and $25 \%$ of total female employment in 2011 (OECD, 2012). Though overall PTE in Turkey is comparable to OECD-34 average for both genders, it is overwhelmingly in the form of informal employment especially for women.

Table 2.1.1: Incidence (\%) of Part-Time Employment by Broad Sectors

\begin{tabular}{c|cccccc}
\hline Year & Gender & Mining & Manufacturing & Construction & Services & Overall \\
\hline 2006 & Male & 0.4 & 0.3 & 1.1 & 0.9 & 0.6 \\
2006 & Female & 0.0 & 0.5 & 0.5 & 1.6 & 1.1 \\
2010 & Male & 0.2 & 0.5 & 1.7 & 1.5 & 1.1 \\
2010 & Female & 0.1 & 0.8 & 1.1 & 2.7 & 2.0 \\
\hline
\end{tabular}

16. Temporary employment (TE) is limited in the formal sector ${ }^{6}$. TE is by far the most prevalent among men in the construction sector. It is slightly more common in services for women and less common in manufacturing for both genders than the overall TE.

Table 2.1.2: Incidence (\%) of Temporary Employment by Broad Sectors

\begin{tabular}{c|cccccc}
\hline Year & Gender & Mining & Manufacturing & Construction & Services & Overall \\
\hline 2006 & Male & 3.3 & 3.0 & 21.1 & 5.3 & 5.3 \\
2006 & Female & 0.9 & 2.5 & 6.6 & 4.2 & 3.5 \\
2010 & Male & 3.7 & 2.3 & 20.3 & 4.7 & 4.7 \\
2010 & Female & 1.8 & 2.4 & 3.7 & 4.4 & 3.7 \\
\hline
\end{tabular}

\footnotetext{
${ }^{5}$ Less than 30 hours work per-week is categorized as part-time work by Labor Code of Turkey.

${ }^{6}$ Less than 30 days of work is categorized as temporary work by Labor Code of Turkey.
} 


\subsection{GAP BY SECTOR AND OCCUPATION}

17. Female employees are more concentrated in the services sector compared to male counterparts. Over the 2006-2010 period both male and female employment in services sector increased at the expense of manufacturing industry employment. That is, source of employment increase in services was mainly shifts from manufacturing. In $2010,61 \%$ of female and $47 \%$ of male employment was in the services.

Table 2.2: Employment by Broad Sectors (\%)

\begin{tabular}{l|cccccc}
\hline Year & Gender & Mining & Manufacturing & Construction & Services & Total \\
\hline 2006 & Male & 2.4 & 50.6 & 5.9 & 41.1 & 100 \\
2006 & Female & 0.4 & 44.8 & 2.5 & 52.3 & 100 \\
2010 & Male & 2.0 & 45.2 & 5.6 & 47.2 & 100 \\
2010 & Female & 0.3 & 36.6 & 2.4 & 60.7 & 100 \\
\hline
\end{tabular}

18. Among disaggregated sectors, health, education and financial services are the ones that female share is comparable to that of male. These sectors are followed by textile and apparel manufacturing with 33\% of employees being female. Trade and other business services follow with rates ranging between $25-30 \%$. At the opposite side, female share is less than $10 \%$ in mining, metal manufacturing, transportation vehicles manufacturing and construction. In spite of the overall increase, female share in machinery manufacturing and to a lesser extent in accommodation and food services decreased over 2006-2010.

19. In line with the sectoral composition, female health and education professionals outnumber their male counterparts. Besides, compared to overall female representation, female are well represented among office staff and other professionals group. Female share in managers occupation is similar to overall female share. On the other hand, with a share of $29 \%$, female representation among managers of small firms (i.e. firms with 10-49 employees) is higher than overall female representation in manager's occupation.

\subsection{GAP BY EducATIONAL ATtAinMENT}

20. Average female employee is more educated than the average male employee.

Figure 2.3.1: Share (\%) by Education

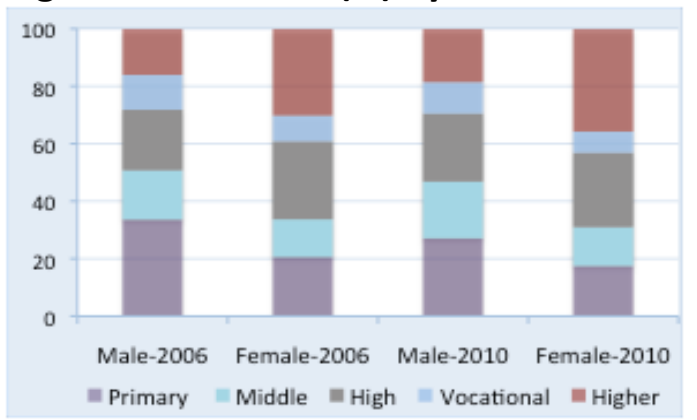

While number of male employees with primary school education was twice as many as male employees with higher education, number of higher educated female employees was $50 \%$ more than primary school educated female employees in 2006. Over the 2006-2010 period, educational attainment of employees in both genders improved. 
21. Female managers are more educated than male managers, though by a smaller margin than the overall education gap between female and male employees. $72 \%$ of female managers and 61\% of male managers were higher educated in both 2006 and 2010. Moreover, only $2 \%$ of female managers and $5 \%$ of male managers were primary school graduates. For both genders, share of higher educated managers in small firms were $6-7 \%$ lower than the overall share of higher educated managers in all managers of that gender.

22. Average female employee is more educated than the average male employee not because female working age population is more educated than male working population but rather female employment is extremely low for low levels of educational attainment, unlike that of male. While employment ratio of male does not show big differences across educational attainment categories, female employment ratio significantly decreases from higher education to high and vocational school. In fact, employment ratio of female with higher education is around twice as much as employment ratio of female with vocational/high school education. In parallel to this, higher education is the only educational group that female employment ratio is close to that of male.

23. Education matters even more when formal employment is considered. Whilst almost all employed women with higher education is formally employed, only $1 / 3^{\text {rd }}$ of middle school and $1 / 5^{\text {th }}$ of primary school graduated women are formally employed among all employed women with corresponding educational levels.

Figure 2.3.2: Employment Ratio (\%) by Educational Attainment, 2012

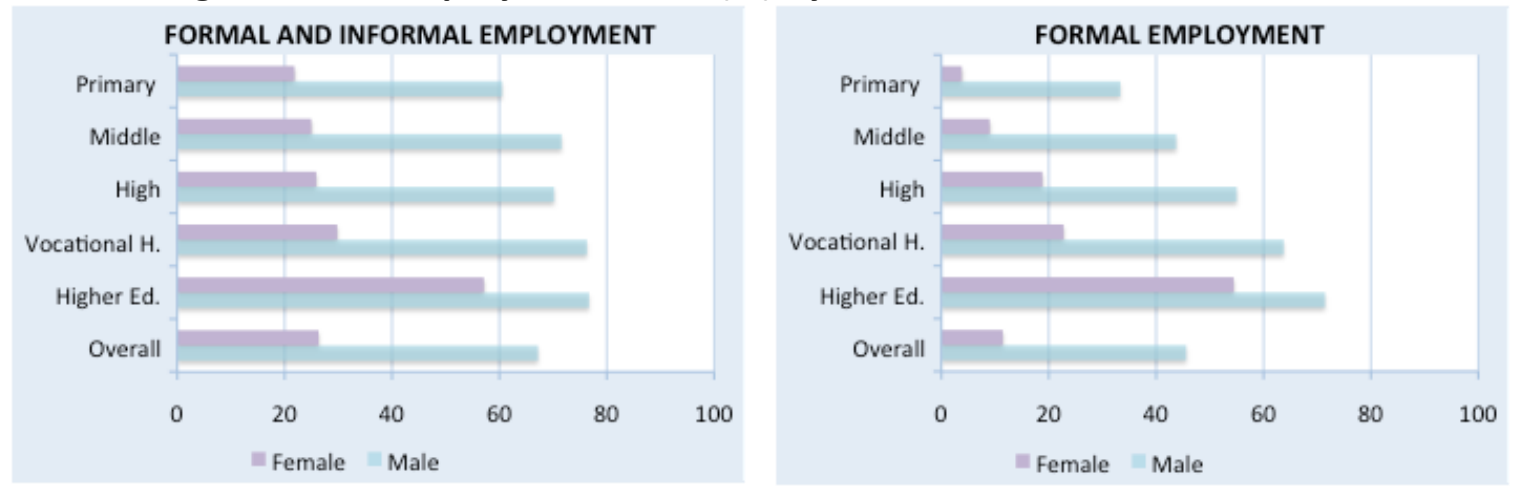

Source: LFS, Turkstat

24. The higher gap in employment ratio in favor of men for low education levels is likely to be indicating that traditional gender roles (i.e. women as mothers and housewives) are more prevalent for lower levels of education. In addition to that, women with low levels of education may not be earning enough to cover the cost of childcare.

25. Female employee is more educated than the male employee even in the same sector and of same profession. In order to check whether educational gap between men and women holds uniformly or it is driven by educational composition in a few selected sector- 
occupation bundles, an index measuring the education of female relative to male in the same sector-occupation is constructed ${ }^{7}$.

26. In Figure 2.3.3, bars with an Index value of above 1 represent sector-occupation bundles in which female is more educated than male. The longer a bar, the higher the number of sector-occupation bundles represented by that bar. Figure clearly shows that female is more educated in most sector-occupation bundles. This shows that the reason for average female employee being more educated than average male employee is not the difference between male and female employees in sectoral or professional concentration (i.e. female concentrated in professions/sectors requiring more education).

Figure 2.3.3: Histogram of Relative Education Index
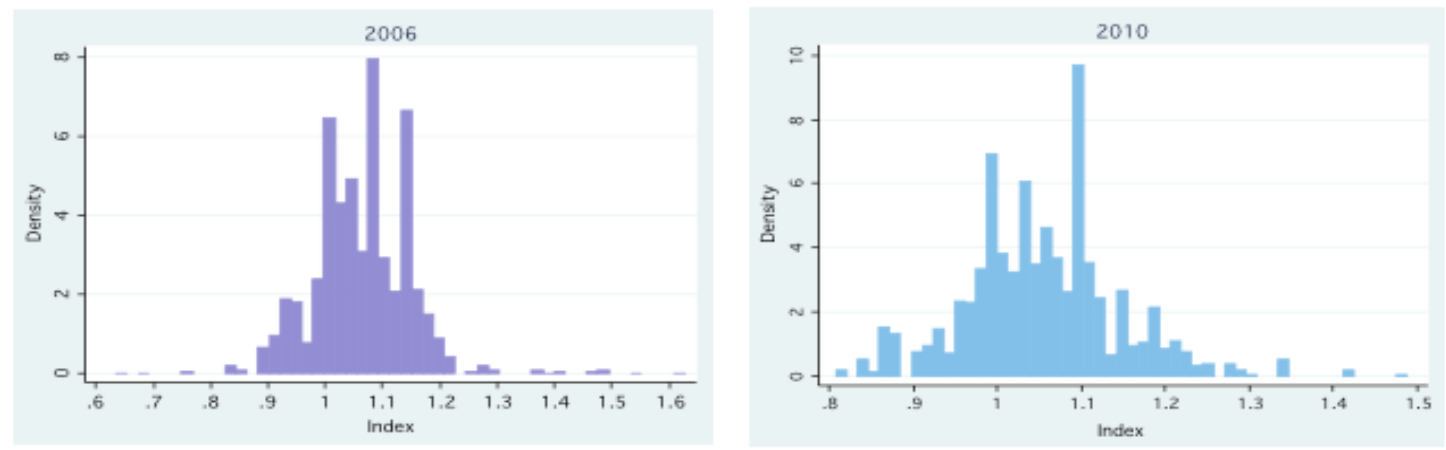

\subsection{GAP BY AGE AND EXPERIENCE}

27. Average female employee is younger and has less years of work experience than the average male employee ${ }^{8}$. Mean age differential was 3.1 years in 2006 and 2.6 years in 2010. Employees in both genders were older in 2010. Mean experience gap decreased slightly from 4.3 to 4.0 .

Table 2.4: Average Age and Experience

\begin{tabular}{|cc|cccc}
\hline \multicolumn{2}{c|}{ Measure } & Female-2006 & Male-2006 & Female-2010 & Male-2010 \\
\hline \multirow{2}{*}{ Age } & Mean & 30.5 & 33.6 & 31.9 & 34.5 \\
& Median & 29 & 32 & 30 & 33 \\
\multirow{2}{*}{ Experience } & Mean & 13.3 & 17.6 & 14.2 & 18.2 \\
& Median & 11 & 17 & 12 & 17 \\
\hline
\end{tabular}

\footnotetext{
7 See Appendix 2.3 for technical details of the Index.

${ }^{8}$ As not reported in the dataset, work experience for an employee is calculated using the following formula: Experience $=$ Previous experience + Current firm experience. Previous experience $=$ Age - Educational years - Current Firm experience. Obviously this formula assumes that there is no gap in the work life of employed, which can not be true for most employees due to military service for male and maternity leave for female as well as unemployment periods. However, as the experience differential between male and female employees is too high, the validity of this assumption is unlikely to affect the analyses considerably.
} 
28. Age and experience differential holds in all sectors except for accommodation \& food services and highest in the health sector, indicating the occupational difference within this sector. No age and experience difference exists among unskilled. In addition, the gap is not due to the differences in the educational attainment of male and female employees. Gap holds within all educational groups except for primary school graduates, where it is almost non-existent.

Figure 2.4.1: Mean Age and Experience by Educational Attainment
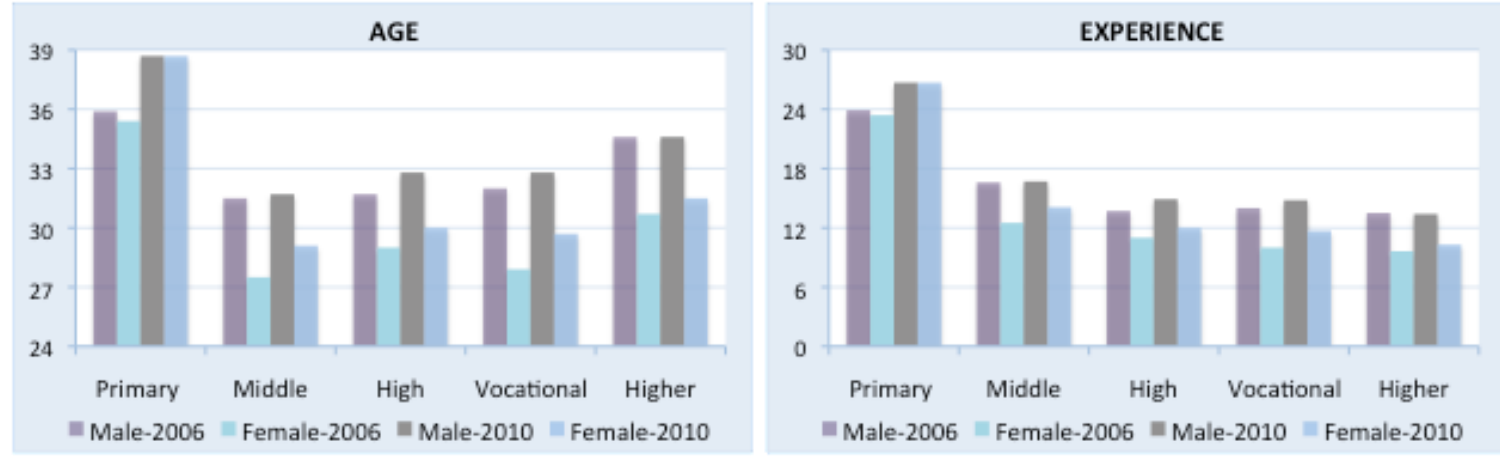

Source: LFS, Turkstat

29. Age and experience gap can be explained by the early exit of female to a large extent. Figure 2.4.2 reveals the steady decline in the female share in employment starting from the age 22 , where female share is equal to male share in employment. Female share gets below its overall average after age 28 in 2006 and 29 in 2010.

Figure 2.4.2: Female Share (\%) in TE by Age

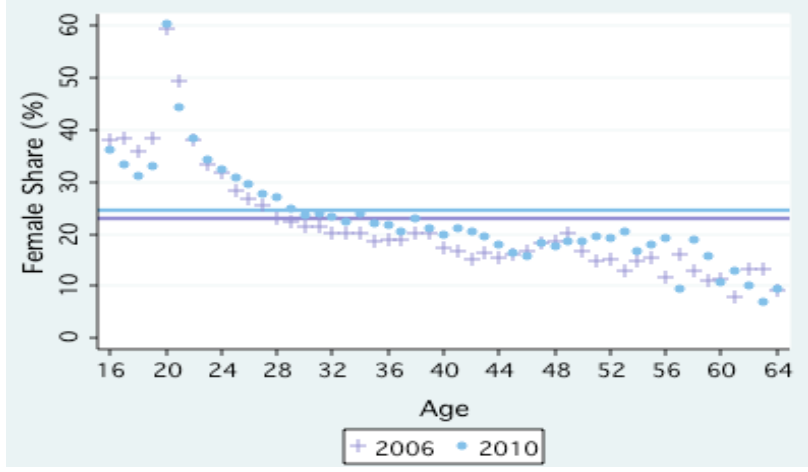

30. The decline is especially strong between ages 22-30. There are two candidates as potential reason for this decline: marriage and child bearing. This finding supports Ilkkaracan (2012) in that women predominantly participate in the labor force at younger ages, prior to marriage and childbirth.

\subsection{Gap Due To Marriage And ChiLd-CARE}

31. Marriage is decisive in the early exit of female. Figure 2.5.1 demonstrates that the difference in the LFP of married men and women accounts for the lion's share of the overall LFP difference between men and women. This is both due to the decrease in the female LFP and increase in the male LFP following marriage, implying the strong influence of traditional roles assigned to female and male in the family. 
Figure 2.5.1: LFP (\%) by Marital Status

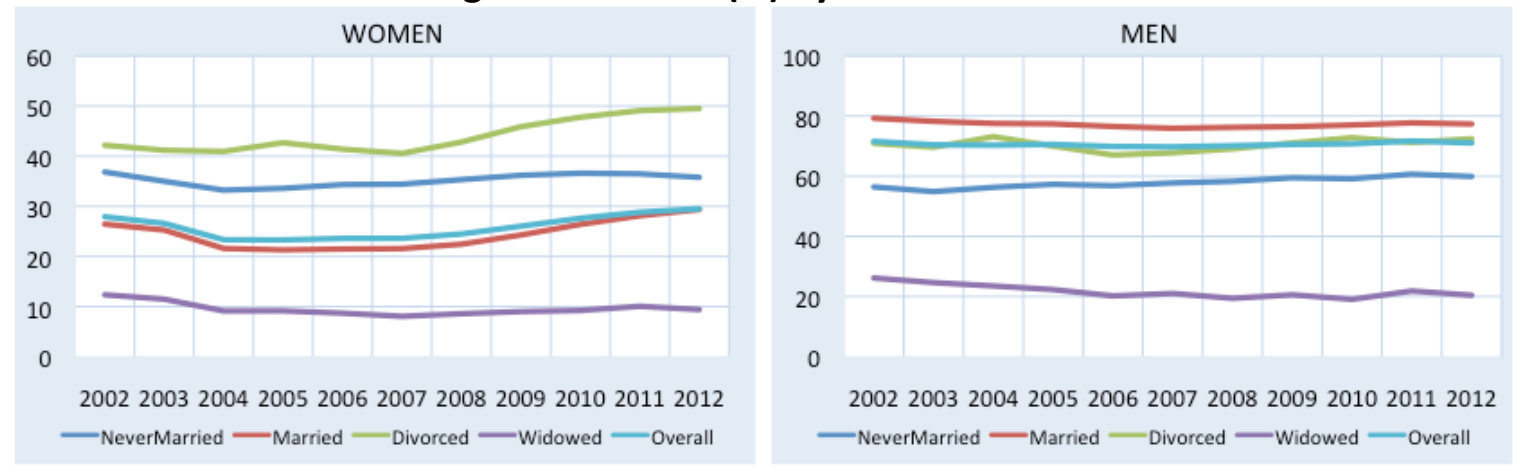

Source: LFS, Turkstat

32. There had been a striking increase in the LFP of married women (from $21.5 \%$ to $29.3 \%$ ) after 2007. During the same period LFP of never married women increased only by 5 percentage points (from $34.3 \%$ to $35.8 \%$ ). This surprising increase in the LFP of married women both in absolute terms and relative to never married women is valid also when rural is excluded from the analysis. In contrast to a mild increase in the LFP of never married female in urban from $35.1 \%$ to $37.4 \%$, LFP of married women in urban experienced an astonishing increase from $15.1 \%$ to $23.2 \%$.

33. The sharp increase in the LFP of married women is likely to be due to cyclical economic conditions rather than favorable shifts in social norms. The partial catch-up in Turkey reminds the growth in the LFP of married women relative to never married in most Latin American countries starting from 1960s. Chioda (2011) documents that increase in the education level of women, favorable shift in the social norms related to work of women, decreasing fertility and shift in the sectoral composition of the economy towards women labor friendly sectors as potential reasons behind this development in Latin America. However, the sharp increase in the LFP of married women in Turkey in a very short period is in a stark contrast with the economic growth observed in the country during the same period. To be more specific, economic crisis that started in 2008 and deepened in 2009 might have required some married women start to work to compensate for the losses in the income of their husbands during the crisis. Besides, it is clear in the Figure that LFP of married women decreased from 2002 to 2004 and was stagnant over 2004-2007, both of which were periods of strong economic growth. This negative correlation between LFP of married women and economic growth can be indicative of need based increase in the LFP of married women after 2007. 
Figure 2.5.2: Female LFP and Marriage

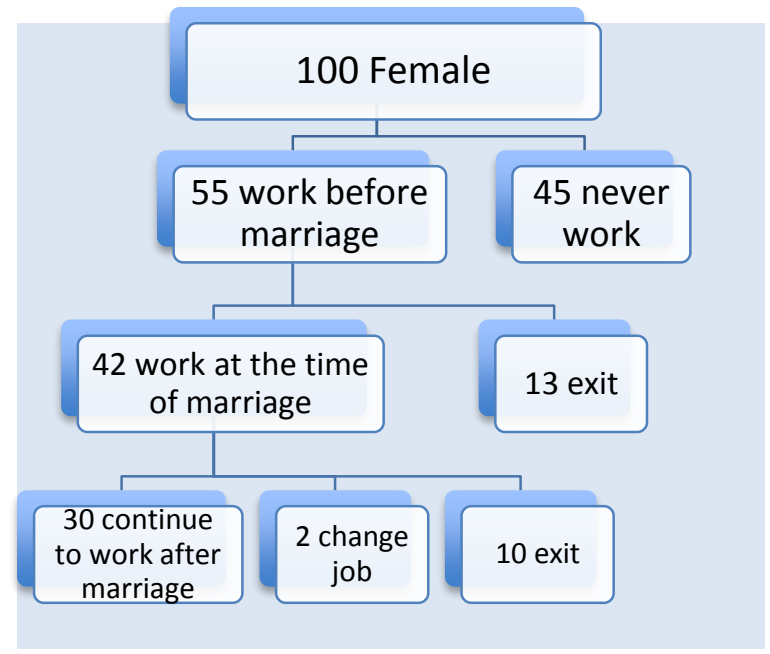

Source: DHS, ICF International
34. Direct evidence for the effect of marriage on female participation comes from Demographic and Household Surveys, undertaken by ICF International. Out of every 100 married women interviewed in 2003 and 2004, 45 reported that she had never worked. 42 of those 55 who worked in the past continue to work at the time of marriage. Finally, following the marriage, 32 of 42 continue to work ( 2 change jobs) and 10 leave the job market.

35. To further investigate marriage related negative factors on female participation, Figure 2.5.3 is built using the same dataset. It presents by educational attainment specific reasons of those \%10 women (see Figure 2.5.2) who leave the job market after marriage out of total $\% 42$ who were working at the time of marriage. Moreover, same reasons might also apply to many of those $13 \%$ who worked before but not at the time of marriage.

Figure 2.5.3: Reasons of Exiting Job Market after Marriage (\%)

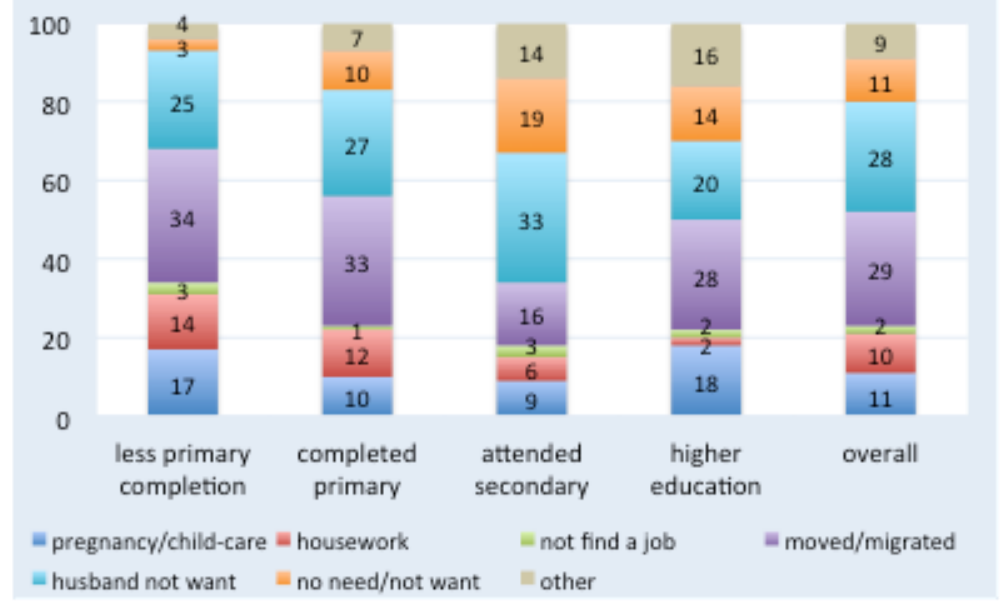

Source: DHS, ICF International

36. Overall, moving to another place and husband's disapproval are main factors in women exiting job market after marriage. Pregnancy and child-care have a share of $11 \%$ and housework has $10 \% .11 \%$ do not need to work or do not prefer to work anymore. Only $2 \%$ report that they could not find a job after marriage. Although not explicitly measured in the Figure, number of children is also likely to be effective on women's participation decision as argued by Dayıoğlu and Kırdar (2010). 
It is noteworthy that husband's disapproval and housework are less important but pregnancy/child-care is a more important reason for higher educated women compared to others. Another important message of the Figure is related with the role of child-care compared to other marriage related reasons. That is to say, only a moderate share of those exiting job market do that due to child-care. This finding for Turkey is similar to that is documented in Chioda and Demombynes (2010) for Latin America: Female LFP reductions are more strongly associated with marriage than child-bearing in Latin American countries.

37. Negative impact of marriage on female LFP decreases by the increase in the educational attainment of women ${ }^{9}$. LFP of married women with primary school education is less than half of the LFP of never married women with same educational attainment. On the opposite end, LFP of married women with higher education is as high as $3 / 4^{\text {th }}$ of the LFP of never married women with higher education. This situation might be indicating that acceptance of traditional roles is weakening with the increase in the education level of women. A contributing factor might be that, unlike the case for women with lower education, higher educated women earn enough to cover childcare costs. On the other hand, the gap between LFPs of never married and married women decreased for all educational groups over 2006-2010.

Figure 2.5.4: Female LFP (\%) by Marital Status and Educational Attainment

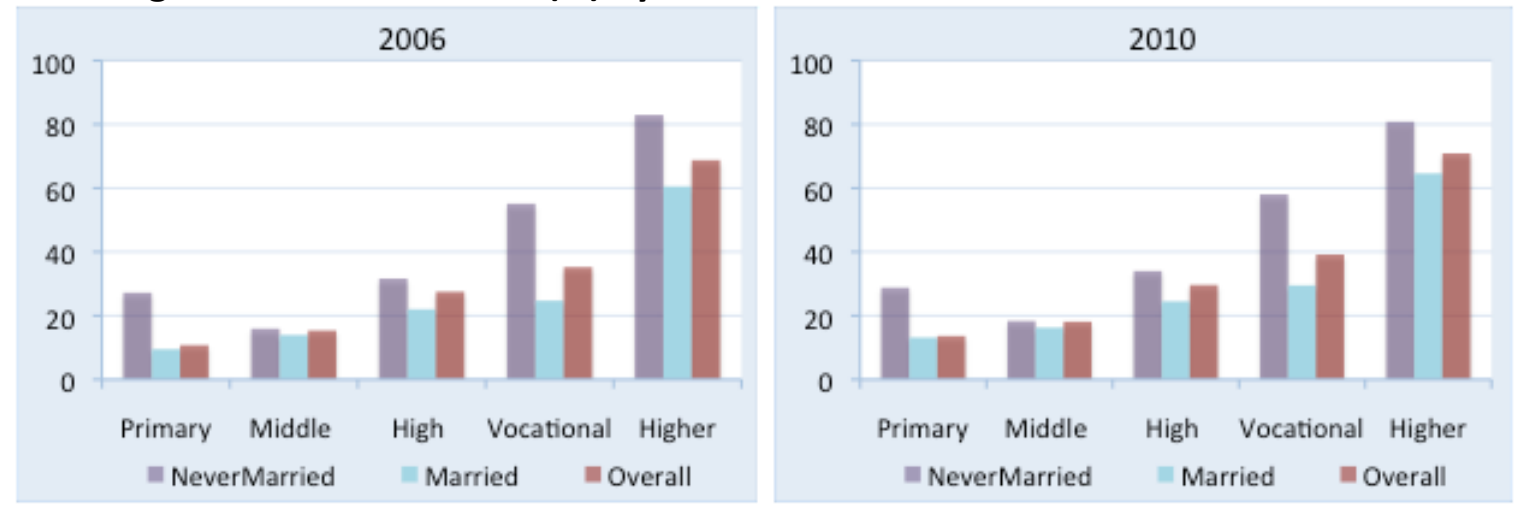

Source: LFS, Turkstat

\footnotetext{
${ }^{9}$ Middle school graduates are an exception to this finding as LFP of single and married women with this education are very close to each other. However, this situation is due to the interestingly low LFP of single women with middle school education, which needs to be further investigated.
} 
38. Given the positive role of higher education in labor force participation of women and particularly for securing a formal job, recent increase in the higher education participation of women might support female LFP in the future. Increase in the marriage age can also contribute to female LFP as staying single supports higher education participation and women with higher education are less likely to exit the job market after marriage. Left Panel in Figure 2.5.5 shows that compared to 2004, ratio of married women are lower for all 20-44 age categories in 2011. This is particularly important for 20-24 and 25-29 age groups as they are higher education ages.

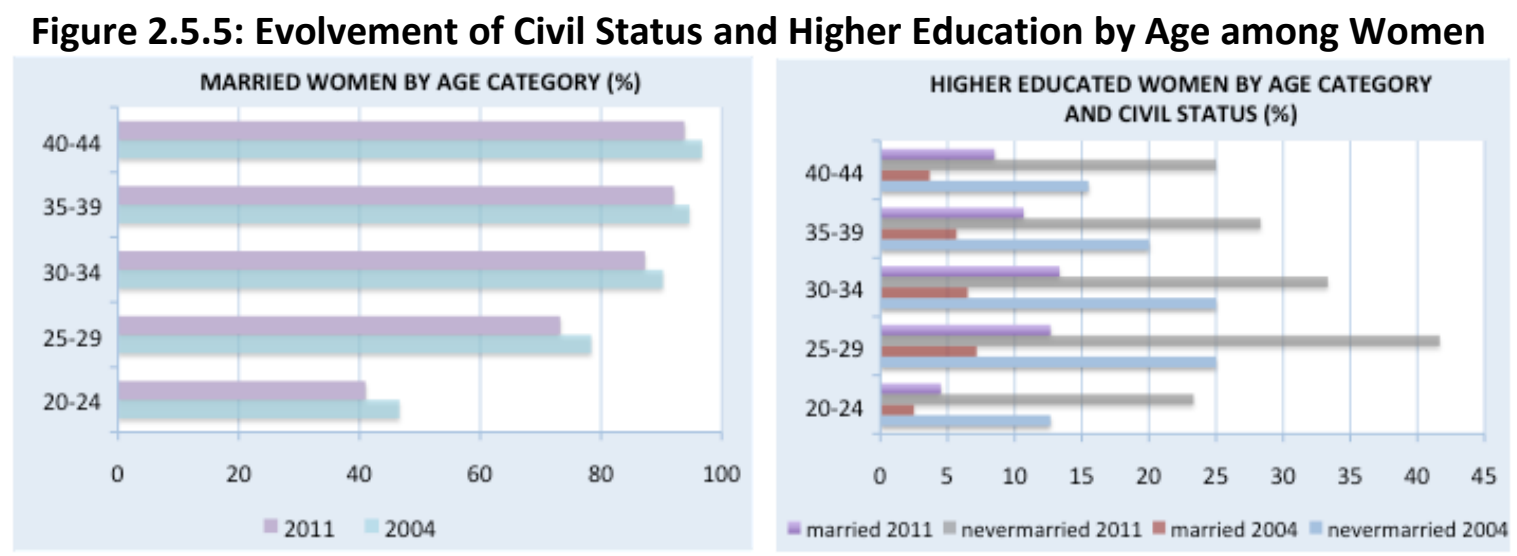

Source: LFS, Turkstat

39. The Right panel of the Figure shows the ratio of higher educated women by civil status and age groups in 2004 and 2011. From 2004 to 2011, ratio of higher educated women increased both for married and never married women in all age groups. Ratio of higher educated among married women doubled for all age groups over 2004-2011. Ratio of higher educated among never married women increased from $25 \%$ to $42 \%$ for the $25-29$ age group and from $25 \%$ to $33 \%$ for the $30-34$ age group over the period.

\section{GENDER GAP IN EMPLOYMENT BY FIRM CHARACTERISTICS ${ }^{10}$}

\subsection{GAP BY FIRM SIZE ${ }^{11}$}

40. Female share in the total employment of a firm increases with the size (total employment) of that firm. Once whole economy is considered, a $1 \%$ increase in the size of a firm is associated with on average a $2.48 \%$ increase in the women share in total employment of that firm. Though, positive relation between firm size and women share holds only within narrow sectors. Once controlled for sub-sectors (i.e. 2-digit NACE sectors ${ }^{12}$ ), response of female share to a $1 \%$ increase in the firm size increases to $3.04 \%$,

\footnotetext{
${ }^{10}$ All computations and Figures in this section make use of Annual Industry and Services Surveys of Turkstat.

11 See Appendix 3.1 for the regression analysis that this section builds on.

12 NACE is the standard classification system of economic activities of the European Community. At 2-digit level, there are 5 mining, 24 manufacturing and 30 services sectors.
} 
implying that, compared to men, women slightly concentrated in sub-sectors with smaller average firm size but in larger firms within a sub-sector. This relationship points a serious disadvantage for female participation in Turkey since small firms have a very large share in the total employment and total number of firms in Turkey compared to several industrialized and developing countries of similar per-capita income (World Bank, 2013).

41. Relationship between firm size and female share significantly differs across broad sectors. Female share in a services firm is, on average, $16.6 \%$ higher than that in a mining firm of similar size. Services are followed by manufacturing and construction sectors, with a $9.8 \%$ and $4.4 \%$ average female share premium over mining sector. However, differential between sectors is not constant as magnitude of the change in the female share in response to a change in the firm size varies across sectors. On average, a $1 \%$ increase in the size of a firm is associated with around $4 \%$ and $3.5 \%$ increase in the female share of a services and manufacturing firm, respectively. On the opposite end, female share in a mining firm decreases with the increase in the size of that firm. For construction, the relationship is almost insignificant.

\section{Figure 3.1: Female Share and Firm Size by Broad Sectors}

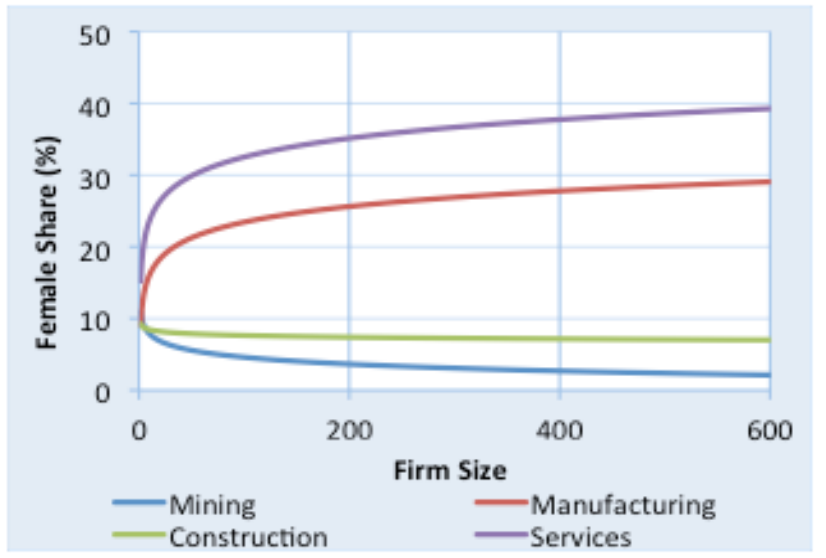

42. Figure 3.1 models the female share and firm size relationship using regression coefficients determined by the specification in the Appendix 3.1. Female share in a single employee firm is estimated to be $10 \%, 8 \%, 8 \%$ and $14 \%$ for mining, construction, manufacturing and services, respectively ${ }^{13}$. As firm size increases until around 200, female share in services and manufacturing firms Source: ISS, Turkstat

sharply. $25 \%$ of all employees of a 200 -employee manufacturing firm and $35 \%$ of a 200 employee services firm are expected to be female. This surge in female share with the increase in firm size continues for after 200-employee threshold, but at a decreasing speed. Hairdressing and washing services, real estate activities, land transportation, hotels and restaurants, manufacture of apparel and retail trade are the sub-sectors with the highest increase in female representation in response to a increase in firm size. On the other hand, female share in a mining firm decreases with the increase in the size of the firm. Only 15 employees of a 1,000-employee mining firm are estimated to be female. In addition to all sub-sectors of mining and construction, female share in renting of machinery and equipment, manufacture of transport equipment, manufacture of basic metals decreases with the increase in firm size.

\footnotetext{
${ }^{13}$ These percentages for a single employee firm obviously describe a hypothetical situation. Percentages can be thought as the probabilities of that employee being woman.
} 


\subsection{GAP BY FIRM LOCATION ${ }^{14}$}

43. Response of female share in a firm to an increase in the employment of that firm varies across regions. Once similar size firms compared, the ranking of regions of Turkey in terms of average female share in total employment of a firm is as follows: Istanbul, West (excluding Istanbul), South, Central, North, East. Specifically, female share in a firm in Istanbul, the highest ranked region, is on average $11.6 \%$ more than the female share in a firm of equal size in the East, the lowest ranked region. On the other hand, as is the case with sectoral differences, the magnitude of the relationship between firm location and female share is not constant. It highly depends on the size of a firm.

Figure 3.2: Female Share and Firm Size by Region

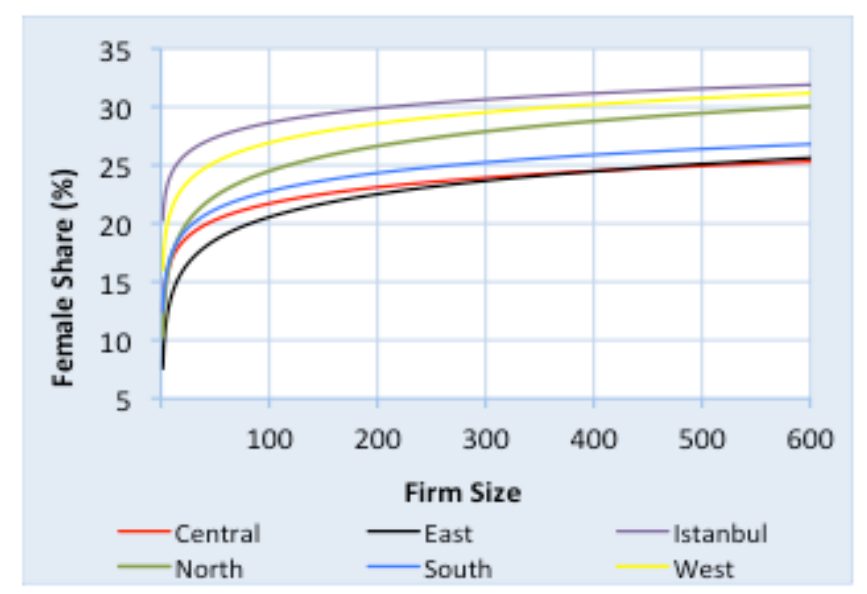

44. Figure 3.2 shows that for a single employee firm female share is estimated to be $8 \%$ in the East, $11 \%$ in the North, $12.5 \%$ in the Central and South, $16 \%$ in the West Turkey and finally $20 \%$ in Istanbul. The magnitude of increase in the female share in response to a $1 \%$ increase in the firm size is as follows by region: North $3.08 \%$, East $2.82 \%$, West $2.37 \%$, South $2.24 \%$, Central $2.00 \%$, Istanbul $1.81 \%$.

Source: ISS, Turkstat

45. This ranking is within expectations from a social perspective. As the East and the North are more traditional than other regions, female participation in these two regions are more repressed for low levels of firm size. Accordingly, female participation gives a stronger response to the increase in the firm size in these regions.

46. Several interesting results emerge from this observed heterogeneity across regions. First, as firm size increases, the North closes the gap with Istanbul and the West. Second, although starts much behind that in Central Turkey, female share in East Turkey surpasses that in Central Turkey around at 400-employee threshold. Between 100 and 600 firm size two regional groups form with female share in the West, Istanbul and the North being roughly $5 \%$ more than those in the South, the Central and the East.

\footnotetext{
${ }^{14}$ See Appendix 3.2 for the regression analysis that this section builds on.
} 
47. Regional differences in female share prevail by a large extent even if they are measured by only using within sub-sector variations. One remaining question is whether disparities across regions in firm size - female share relationship are driven by differences in sectoral composition of different regions. That is to say, if services sector has a bigger share in the economy of Istanbul than those of other regions, we can expect Istanbul to have higher female share even if there is no regional effect associated with Istanbul. To examine this question, disparities among regional female share averages are measured only within sectors and sub-sectors. Once broad sectors are controlled, relative to the female share in the East, average female share in Istanbul, the Central and the West increase whereas those in the North and the South decrease slightly. A larger change occurs once sectoral averages are generated only by within sub-sector variations. In that case, Istanbul premium (over the East) decreases from $11.64 \%$ to $10.69 \%$. Similarly, premium of the Central, the South and the West decrease. On the other hand, premium of the North increases from $2.80 \%$ to $3.22 \%$. These figures imply that unfavorable (i.e. female unfriendly) sectoral composition of the North and the East have limited role in these two regions' lagging behind others in average female share.

\section{GENDER GAP IN EARNINGS: PRELIMINARY ANALYSIS}

\subsection{COMPARISON OF HOURS WORKED}

48. Average working hour of female is comparable to that of male. Difference between male and female regular weekly work is very low in favor of male. Difference in overtime work was slightly higher and increased from 2006 to 2010 in parallel to the increase of overtime work for both genders. ${ }^{15}$

Table 4.1: Average (Mean) Weekly Work Hours (full time and permanent)

\begin{tabular}{l|cccc}
\hline Work Type & Female-2006 & Male-2006 & Female-2010 & Male-2010 \\
\hline Regular & 44.7 & 44.9 & 44.4 & 44.7 \\
Overtime & 0.7 & 1.2 & 0.9 & 1.6 \\
Total & 45.5 & 46.1 & 45.3 & 46.3 \\
\hline
\end{tabular}

49. Similarity of hours worked holds at finer levels of classifications. In none of the sectors, occupational or educational groups, the difference between average working time of female and male is more than 2 hours per-week. Financial services is the sector that has the least work time with 42 hours for both genders and transportation vehicles manufacturing is the one that has longest with 48 hours for male and 47 hours for female.

\footnotetext{
${ }^{15}$ These figures are computed over all employees. Only $19 \%$ of male and $15 \%$ of female reported to have overtime work in 2010. Therefore, average over-time work among males that reported overtime work was 8.4 hours $(=1.6 \mathrm{hrs} * 100 / 19)$ per week in 2010.
} 


\subsection{OVERALl GAP IN EARNINGS}

50. Average per-hour earning of women is not less than that of male. Women earned, on average, $0.5 \%$ and 3\% more than the men per-hour worked in 2006 and 2010.

Table 4.2.1: Gross Earnings (TL) per-hour worked

\begin{tabular}{c|ccc}
\hline Female-2006 & Male-2006 & Female-2010 & Male-2010 \\
\hline 6.16 & 6.13 & 8.63 & 8.37 \\
\hline
\end{tabular}

51. Basic wage is the primary source of earnings for both genders. ${ }^{16}$ Share of basic wage in total earnings was $85.4 \%$ for female and $81.8 \%$ for male in 2010 . On the contrary, regular payments other than basic wage had a higher share in total earnings of male.

Table 4.2.2: Share (\%) of Each Earning Type in Total Earnings - 2010

\begin{tabular}{l|ccccc}
\hline Gender & Basic Wage & $\begin{array}{c}\text { Regular } \\
\text { Payments }\end{array}$ & $\begin{array}{c}\text { Irregular } \\
\text { Payments }\end{array}$ & $\begin{array}{c}\text { In-kind } \\
\text { Transfers }\end{array}$ & Total \\
\hline Female & 85.4 & 5.4 & 6.7 & 2.5 & 100 \\
Male & 81.8 & 8.4 & 7.0 & 2.8 & 100 \\
\hline
\end{tabular}

\subsection{GAP BY SECTOR AND OCCUPATION}

52. Female earn less in manufacturing but more in services than the male in the same sector. Gap in earnings per-hour decreased from $23 \%$ to $19 \%$ in manufacturing and from $10 \%$ to $8 \%$ in services over $2006-2010$. On the other hand, average earning in services was higher than that in manufacturing even for men.

53. Among sub-sectors, textile manufacturing was the lowest paying sector followed by construction for both genders in both years. Average earnings in the financial services, the highest paying sector, were more than 4 times in textile manufacturing. ${ }^{17}$ As for occupational differences, female managers earned on overage $10 \%$ more than male managers. Female earnings was $2 / 3^{\text {rd }}$ of that of male among health professionals, indicating the different roles within the broad definition of health professional.

\footnotetext{
${ }^{16}$ Regular payments: Bonuses, in-cash social contributions, overnight and overtime transfers paid every month. Irregular payments: Irregular transfers of those classified under regular payments as well as any other non-monthly cash transfers such as dividend payments and marriage contribution. In-kind transfers: Any contributions that are not in cash such as free lunch.

17 Single minimum wage policy affected earnings structure of sectors by varying magnitudes. See Appendix 4.3 for the comparison of its effects on financial services sector and textile \& manufacturing sector. It has almost no effect in financial services sector, on the opposite hand, has a tremendous effect in the textile and manufacturing sectors.
} 
Figure 4.3: Hourly Earnings of Female (as \% of male earnings in the same sector/occu)
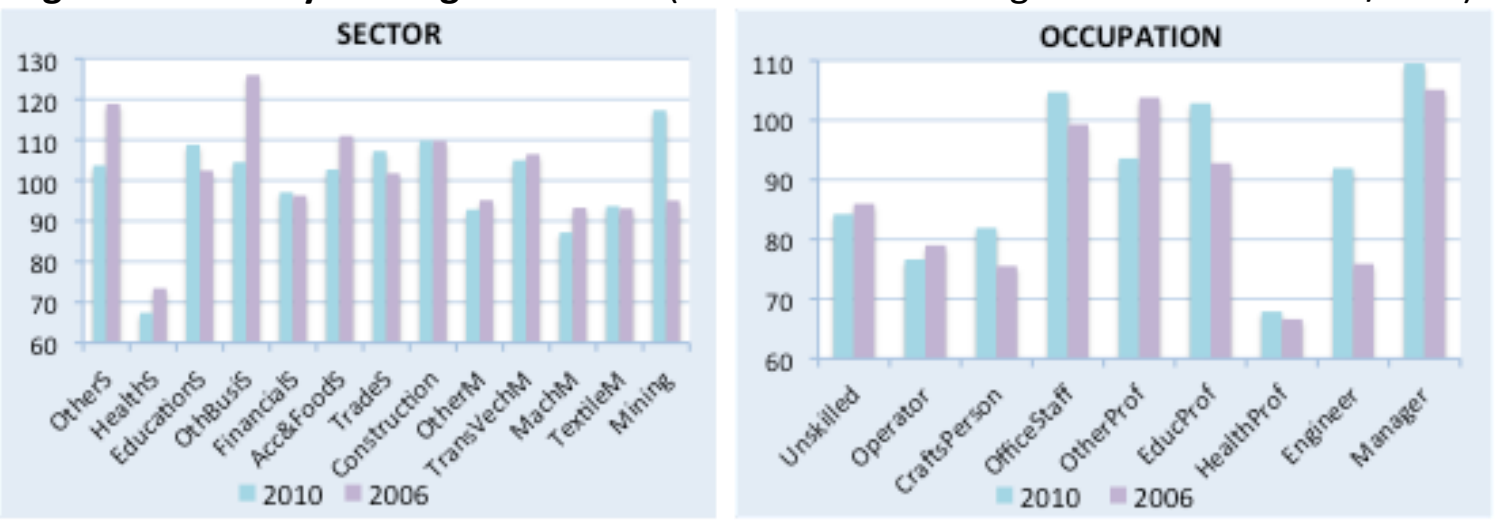

\subsection{GAP BY EducATIONAL ATtAinMENT}

54. Female earn significantly less than the male with same educational attainment. Although, average earnings of female was slightly more than that of male, female earn less than the male with same education, confirming the vast difference in the educational composition of female and male employees. Turkish labor market is not an exception in this behavior. Atal et al. (2009) report that earnings gap in Latin America increases by $12 \%$ if gap is measured within educational groups.

Figure 4.4: Hourly Earnings of Female (as \% of male earnings with same education)

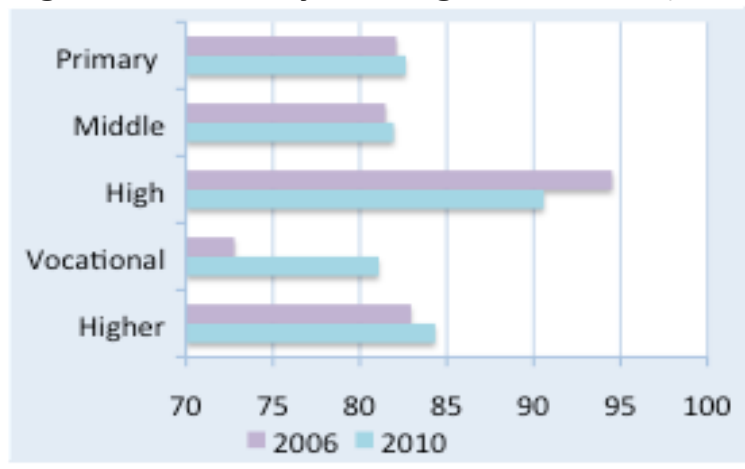

55. Earnings gap was highest within vocational school graduates and lowest within high school graduates in 2006. Over the 2006-2010 period, gaps in both groups decreased. As for within gender comparison, primary and middle school graduates of male and female earned exactly same and around $1 / 3^{\text {rd }}$ of higher education graduates in both years.

\subsection{GAP BY YEARS OF EXPERIENCE}

56. Female earnings relative to male earnings show a heterogeneous trend by years of experience. 3 zones emerge out of the structure in Figure 4.5:

I- Until 6 years of experience men and women earn almost same. Average ages of men and women in this group are 23.0 and 22.8 , respectively. 
Figure 4.5: Hourly Earnings of Female (relative to male with same experience)

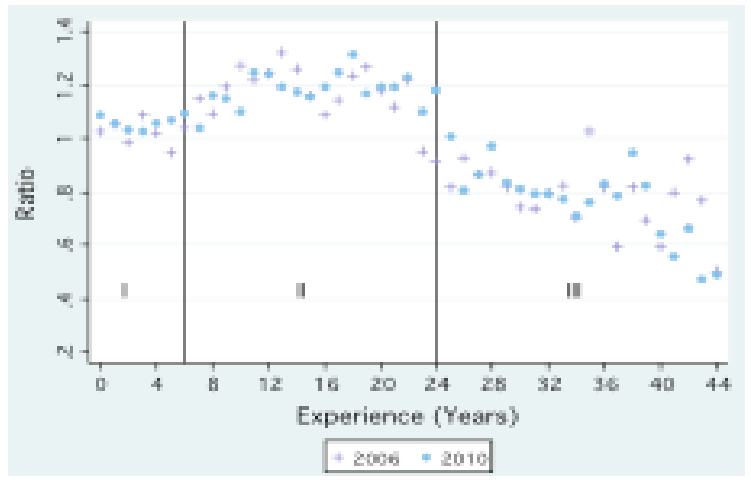

II- Between 7 and 24 years of experience female earn $10-30 \%$ more than the male with same years of experience.

III- Starting from around 25 years of experience, female earnings relative to male is decreasing persistently by years of experience. At 44 years of experience, female earn around half of male.

\section{GENDER GAP IN EARNINGS: REGRESSION ANALYSIS ${ }^{18}$}

57. Descriptive analysis in Section four demonstrated that there are several factors potentially effective on the gender gap in earnings. Regression analysis in this section allows us to detect individual magnitudes of those factors.

58. Regression analysis confirms that average female employee does not earn less than the average male employee. Average per-hour earnings was 5.67 TL and 5.70 TL in 2006; 8.37 $T L$ and $8.63 \mathrm{TL}$ in 2010 for men and women, respectively. That is, earnings gap was in favor of women. As for managers, there was no gap between men and women in 2006 but it was 55 cents, corresponding to a $6 \%$ difference, in favor of women managers in 2010 . On the other hand, direction of gender gap was opposite in manufacturing and services. In 2010, average female employee earned 1.22 TL (16\%) less in manufacturing but 0.74 TL (8\%) more in services than the average male in the same broad sector.

59. If education level is not taken into account, it is found that female employees are concentrated in higher-paying sectors and sub-sectors compared to male employees. This result is not surprising given that female representation was above overall female representation in the highest (financial services), $3^{\text {rd }}$ highest (education) and $5^{\text {th }}$ highest (health) paying sectors. Once controlled for sub-sector, gender premium for women decreases by $0.38 \mathrm{TL}$ and becomes negative implying that women earned $0.12 \mathrm{TL}$ less than men in the same sub-sector. This result is driven by the earning differentials in sub-sectors of manufacturing rather than those of services. On the other hand, both men and women earn more in services than in manufacturing. In 2010, per-hour earnings in services were on average $25 \%$ and $60 \%$ higher than those in manufacturing for men and women, respectively.

\footnotetext{
${ }^{18}$ See Appendix 5 for the regression analysis that this section builds on.
} 
60. Once education level and experience are taken into account, it is found that differences in sectoral and occupational segregation of male and female employees contribute to the earnings gap. As explained, the average female employee works in higher-paying sectors and sub-sectors compared to average male employee. However, as also explained, the average female employee is more educated but less experienced than the average male employee. If earnings of men and women of same educational attainment and years of experience are compared within sub-sectors, there emerges a small segregation in favor of men. To illustrate, earnings of female was 0.22 TL less than male of same occupation, with same educational attainment and same current firm and previous experience in 2010 . However, earnings disparity without sub-sector control, (i.e. gap explained by both within and between occupation differences between male and female with same education, current firm and previous experience) was $0.32 \mathrm{TL}$ in favor of men. Therefore, it can be concluded that women were more segregated into lower paying sub-sectors compared to men with same education but this tendency was very weak. The same is true for occupational segregation. Female employees are weakly segregated into lower paying occupations relative to male of similar characteristics.

61. Sectoral and occupational segregation contributes to the earnings gap only within manufacturing. In 2010, women working in manufacturing earned 0.42 TL less due to concentrating in lower paying sub-sectors and 0.34 TL less due to concentrating in lower paying occupations. On the other hand, earnings gap originating from sub-sectoral and occupational segregation of male and female employees within services is negligible.

62. Compared to men, women work in higher paying firms in a sub-sector. However, women earn significantly less than the men in the same firm. Once sub-sector controls are replaced by firm controls, gender premium for women, which was already negative in 2010, decreases further by a large magnitude for both years. On average, women earned perhour $0.91 \mathrm{TL}(11 \%)$ less than the men working in the same firm, respectively in 2006 and 2010. Within firm gap was 4\% in manufacturing and $13 \%$ in services in 2010.

63. Although, in general, women earn less than the men with the same educational attainment, direction and magnitude of the gap differs across educational attainment groups. On the one hand, in 2010, primary school and higher educated women earned $12 \%$ and $8 \%$ less than the men with same educational attainment and equal years of within firm and previous experience ${ }^{19}$. On the other hand, middle, high and vocational high school graduated women earned more than the men with same years of experience by $1 \%, 6 \%$ and $1 \%$, respectively.

\footnotetext{
${ }^{19}$ Average earnings of women with a formal job and at most primary school graduated are slightly above the minimum wage.
} 
64. Once comparison is limited to those working in the same sub-sector or in the same firm, the earnings gap between primary school graduated male and female employees decreases to $2 \%$. However, earnings gap among university educated male and female employees increases to $12 \%$ if male and female working in the same firm are compared. Gap for other educational groups do not change considerably by within sub-sector or firm comparison. On the other hand, earnings variation across different educational attainments is striking for women. A university educated female earns on average four times as much as a female with primary school education and twice as much as a female with high school education.

65. Women having less experience contributes significantly to the earnings gap. On average, in 2010, a man employee earned 0.61 TL and 0.14 TL more than another man employee with same educational attainment but with 1 year less experience in the current firm and previous firm, respectively. Contribution of additional year of experience is even more for a woman. It is $0.72 \mathrm{TL}$ and $0.18 \mathrm{TL}$, for 1 year of current and previous firm experience, respectively. Premium of additional year of experience does not change significantly if employees within same sub-sector are compared. On the other hand, current firm experience premium decreases to $0.49 \mathrm{TL}$ for men and to $0.50 \mathrm{TL}$ for women if employees with same education and working in the same firm are compared.

66. Gender gap in earnings that can be attributed to discrimination against women is not large in the formal labor market in Turkey. Women earn slightly less than the men with same education and occupation, working in the same firm and having same years of current firm and previous experience. The gap was 5.5\% (0.33 TL) and 6.5\% (0.54 TL) for overall economy, $5.7 \%$ and $2.7 \%$ for manufacturing and $4.8 \%$ and $6.9 \%$ for services, in 2006 and 2010 , respectively. That is, the gap decreased in manufacturing but increased in services over 2006-2010. Under the assumption that all characteristics effective on the level of wages are controlled, figures above give the magnitude of discrimination against women in the formal labor market.

67. Gender gap earnings in Turkey is highly likely to grow with the increase in female LFP. The measured discrimination in Turkey is much lower than those measured for many countries in various studies referred in the Introduction. One coverage related and one country-specific reason likely to account for this differential. As for coverage, unlike many other studies, this study measures the earnings gap only in the formal labor market. It is well established in the literature that earnings discrimination against women in informal jobs are higher than that in formal ones ${ }^{20}$. As for the country-specific reason, extremely low participation rate of female, compared to male in Turkey and also to female in other countries, gives female employees a higher bargaining power in Turkey. Underlying this reasoning is the assumption put by Katz and Murphy (1992) that men and women are "imperfect substitutes" in the labor market. In fact, Blau and Kahn (2001) show for 22 industrialized and transition countries that there is a positive relationship between earnings gap in favor of men and female labor supply in a country ${ }^{21}$.

\footnotetext{
20 See, for example, Cornish (2007), Nordman et al. (2009), Nopo et al. (2011)

21 Instead of relying on the results of other countries, the ideal approach would be to analyze labor supply and earnings gap relationship in Turkey. However, lack of a long series of panel data for Turkey makes such an analysis impossible.
} 


\section{CONCLUSION AND POLICY IMPLICATIONS}

68. Using novel datasets, this paper has revealed several distinctive features of the gender dimension of formal labor market in Turkey. In light of these findings, certain areas emerge as candidates for policy interventions in achieving gender equity in the Turkish economy:

69. First, higher education is a critical factor for the female labor force participation since female participation is extremely low for low levels of educational attainment, unlike that of male. It is even more important for women to secure a formal job. Therefore, encouraging female to continue education after mandatory primary education is likely to yield positive results. Although increase in the higher education attendance may not help decrease the existing earnings gap between higher educated men and women, it would still make women better off since higher educated women earn several times more than those without higher education. Increase in the education level is likely to also have a positive effect on female entrepreneurship as higher education is the dominant education type among female entrepreneurs of all and also small-sized formal firms.

70. A significant drawback of working women is that, compared to men, they have less experience due to early exit. Marriage and childcare are decisive in the early exit of women that do not have higher education. These effects work through traditional role assignment in the family and inability of low educated women to earn enough to cover childcare and other work related costs. Hence, a second area of intervention might be to introduce cheap and prevalent childcare facilities for working women.

71. Third area of intervention can be to support formal part-time employment of female as part-time formal employment is still rare especially for women. Legal reforms in the area of social security that will make part-time work more attractive for both employees and employers as well as policies to increase the formalization of part-time employment might be priority actions. On the other hand, potential adverse effects of such policies need to be considered. Since most part-time employment is informal, promoting part-time employment can easily contribute to informal employment or result in already full-time employed women to become part-time employed.

72. The forth and fifth interventions are related to firm characteristics. Female share in the total employment of a firm shows a robust increase with the size of that firm in the services and the manufacturing industry. That is, women work in larger firms compared to men. Moreover, female share increases the most in the East and the North, which are comparatively conservative regions, with the increase in the firm size. These findings hint that social norms related to work of women and insecurity of women in the small-sized firms might be functional in the low participation of female. Therefore, improving labor related legislations to better protect women rights in the work environment might help boost the interest of women to work in small-sized firms. 
73. As a consequence of the positive relationship between firm size and female share in a firm, policies aiming at developing small and medium sized enterprises (SME) have an indirect positive effect on the female participation to the labor market. Although SME development is a subject of a broader development agenda, it may be further supported due to its positive externality on female participation. Accordingly, improving and expanding industrial zones can be helpful as they provide a more secure work environment and better transportation facilities.

74. Shaped by the higher educational level but also less work experience of women, earnings of women relative to those of men do not indicate a significant earnings discrimination in the formal labor market in Turkey. However, earnings gap needs to be considered together with the record low participation rate of women. A higher participation of women is likely to raise the earnings gap in Turkey to the level of those existent in countries with high female labor force participation. 


\section{REFERENCES}

Atal, J.P., H. Nopo and N. Winder (2009). "New Century, Old Disparities. Gender and Ethnic Wage Gaps in Latin America," Inter-American Development Bank Research Department Working Paper No. 109.

Blau F. and L. Kahn (2001). "Understanding International Difference in the Gender Pay Gap," NBER Working Paper No. 8200.

Blinder, A. S. (1973). "Wage discrimination: reduced form and structural estimates," Journal of Human Resources 8 (4), 436-455.

Chioda L., and G. Demombynes (2010). "The Rise of Female Labor force Participation Rate in LAC, 1960-2000," World Bank.

Chioda, L. (2011). "Work and Family: Latin American and Caribbean Women in Search of a New Balance," World Bank.

Cornish, M. (2007) “Closing The Global Gender Pay Gap: Securing Justice for Women's Work," Comparative Labor Law \& Policy Journal, 28(2), 219-249.

Dayioglu, M., and M. G. Kirdar (2010). Determinants of and Trends in Labor Force Participation of Women in Turkey," Ankara: State Planning Organization and World Bank.

Elder, T. E., J. H. Goddeeris, S. J. Haider (2010). “Unexplained gaps and Oaxaca-Blinder decompositions," Labour Economics, 17: 284-290.

Fernandez R., and A. Fogli (2009). "Culture: An Empirical Investigation of Beliefs, Work, and Fertility," American Economic Journal: Macroeconomics, 1(1), 146-147.

Fryer, R., and S. Levitt (2004). "Understanding the black-white test score gap in the first two years of school," Review of Economics and Statistics, 86 (2), 447-464.

Goksen, F., O. Olcay, A. Alniacik, and C. Deniz (2013). “Analysis of Public Programs Relevant to Women's Entrepreneurship and Access to Labor Markets," Koc University Social Policy Center Working Paper.

Hausmann, R., L. D. Tyson, and S. Zahidi (2012). “The Global Gender Gap Report," World Economic Forum. Geneva, Switzerland.

Hertz, T., P. Winters, A. P. de la O Campos, E. J. Quinones, B. Davis, and A. Zezza (2008). "Wage Inequality In International Perspective: Effects of Location, Sector, And Gender," ESA Working Paper No. 08-08.

Hoyos, A. and H. Nopo (2010). "Evolution of Gender Gaps in Latin America at the Turn of the Twentieth Century: An addendum to New Century, Old Disparities," Inter-American Development Bank Research Department Working Paper No. 176. 
International Labor Organization (2001). "Women, Gender and Work," Geneve, Switzerland: ILO.

Ilkkaracan, I. (2012). "Why so Few Women in the Labor Market in Turkey?," Feminist Economics, 18:1, 1-37.

Katz, L. F., and K. M. Murphy (1992) "Changes in Relative Wages, 1963-87: Supply and Demand Factors," Quarterly Journal of Economics, 107: 35-78.

Levinsohn, J. and A. Petrin (2003). "Estimating Production Functions Using Inputs to Control for Unobservables," Review of Economic Studies, 70, 317-341.

Neal, D. A., W. R. Johnson, (1996). "The role of premarket factors in black-white wage differences," Journal of Political Economy, 104 (5), 869-895.

Nopo, H., N. Daza, and J. Ramos (2011). "Gender Earnings Gaps in the World," IZA Discussion Paper No. 5736.

Nordman, C. J., F. Rakotomanana, and A. S. Robilliard (2009). "Gender Disparities in the Malagasy Labor Market," DIAL Working Paper No. 8.

Oaxaca, R. (1973). "Male-female wage differentials in urban labor markets," International Economic Review 14 (3), 693-709.

OECD (2012). "Gender Differences in Employment Outcomes," Paris, France: OECD.

Pastore, F. (2010). "The Gender Gap in Early Career in Mongolia," International Journal of Manpower, 31(2):188-207.

Simon, H. (2007). "The Gender Pay Gap in Europe: An International Comparison with Matched Employer-Employee Data," Alicante, Spain: Universidad de Alicante.

Tansel, A. (2004) "Public-Private Employment Choice, Wage Differentials and Gender in Turkey," IZA Discussion Paper No. 1262.

Tzannatos, Z. (1999). "Women And Labor Market Changes In The Global Economy: Growth Helps, Inequalities Hurt and Public Policy Matters," World Development, 27(3), 551-569.

World Bank (2012). "World Development Report: Gender Equality and Development," Washington DC, USA: World Bank.

World Bank (2013). "Good Jobs in Turkey," Ankara, Turkey: World Bank. 


\section{APPENDIX}

\section{A2.3 Relative Education IndeX}

$$
\text { Index }_{i j}=\left(\sum_{f} E d u c_{f} / N f\right) /\left(\sum_{m} E d u c_{m} / N m\right)
$$

where $i$ represents sector, $j$ occupation, $f$ female employee, $m$ male employee. $N f$ is the number of female in the sector-occupation, $\mathrm{Nm}$ is the number of male in the sectoroccupation and Educ is the duration of educational attainment of an employee such that:

$$
\text { Educ }=\left\{\begin{array}{l}
5, \text { if educationalattaintment }=\text { "primary" } \\
8, \text { if educationalattaintment }=\text { "middle" } \\
11, \text { if educationalattaintment }=\text { "high" or "vocational } \\
14, \text { if educationalattaintment }=\text { "higher" }
\end{array}\right.
$$

Assignment of duration to each educational attainment is a critical step in computing the Index. 5 years is chosen for "primary" although this group includes employees that have less than 5 years of education or no education at all. Given that "primary" is a larger group for males, this choice is likely to result in a downward bias in the index rather than an upward bias. For robustness, computations repeated under various scenarios of education durations and obtained similar results at all attempts.

\section{A3.1 GAP BY FIRM SIZE}

$$
F S_{f y}=\beta_{0}+\beta_{1} \text { Employment }_{f y}+\beta_{2} \text { Sector }_{f y}+\beta_{3} \text { Employment }_{f y} * \text { Sector }_{f y}+\varepsilon_{i t}
$$

$f$ represents firm and $y$ year. FS is \% share of female employees in the total employees of a firm, Employment is log number of employees of a firm and Sector is a dummy representing the broad sector (i.e. mining, manufacturing, construction or services) a firm operates. Omitted category for the Sector is mining. A Sub-sector corresponds to a 2-digit code of NACE Rev. 1.1.

Table A3.1: Results of Specification A3.1

\begin{tabular}{l|cccc}
\hline REGRESSOR & (1) & (2) & (3) & (4) \\
\hline Employment & 2.48 & 3.04 & 3.29 & -1.38 \\
Manufacturing & & & 9.75 & -1.90 \\
Construction & & & 4.36 & -1.72 \\
Services & & 16.61 & 4.26 \\
Manuf*Empl & & & 4.51 \\
Const* Empl & & & 1.03 \\
Services* Empl & & & -0.95 & 5.14 \\
Constant & 14.72 & 14.21 & $6.01 \mathrm{mn}$ & $6.01 \mathrm{mn}$ \\
\hline N. of Obs. & $6.01 \mathrm{mn}$ & $6.01 \mathrm{mn}$ & 0.08 & 0.08 \\
$\mathrm{R}^{2}$ & 0.06 & 0.19 & \multirow{2}{*}{ Year } & Year \\
\hline Fixed Effects & \multirow{2}{*}{ Year } & Year ${ }^{*}$ & & \\
\hline
\end{tabular}

*All coefficients significant at $1 \%$ 


\section{A3.2 GAP BY FIRM LOCATION}

$$
F S_{f y}=\beta_{0}+\beta_{1} \text { Employment }_{f y}+\beta_{2} \text { Region }_{f y}+\beta_{3} \text { Employment }_{f y} * \text { Region }_{f y}+\varepsilon_{i t}
$$

In the specification, Region is a categorical variable for the location of firms and takes one of East, Istanbul, Central, North, South or West. Omitted category is the East.

Table A3.2: Results of Specification A3.2

\begin{tabular}{l|cccc}
\hline REGRESSOR & $(\mathbf{1})$ & $(\mathbf{2})$ & $(\mathbf{3})$ & $(\mathbf{4})$ \\
\hline Employment & 2.20 & 2.82 & 3.02 & 2.91 \\
Istanbul & 11.64 & 12.73 & 11.95 & 10.69 \\
Central & 4.12 & 4.91 & 4.41 & 3.90 \\
North & 2.97 & 2.75 & 2.80 & 3.22 \\
South & 4.35 & 4.88 & 4.19 & 3.92 \\
West & 8.03 & 8.44 & 8.20 & 8.13 \\
Istanbul*Empl & & -1.01 & & \\
Central*Empl & & -0.82 & & \\
North*Empl & & 0.26 & & \\
South*Empl & & -0.58 & & \\
West*Empl & & -0.45 & & \\
Constant & 8.13 & 7.56 & 7.12 & \\
\hline N. of Obs. & $6.01 \mathrm{mn}$ & $6.01 \mathrm{mn}$ & $6.01 \mathrm{mn}$ & $6.01 \mathrm{mn}$ \\
$\mathrm{R}^{2}$ & 0.08 & 0.08 & 0.10 & 0.20 \\
\hline Fixed Effects & Year & Year & Year*Sector & Year*Sub-Sector \\
\hline
\end{tabular}

*All coefficients significant at $1 \%$

\section{A4.3 Distribution Of EARNINGS}

Figure A4.3: Distribution of Monthly Earnings*
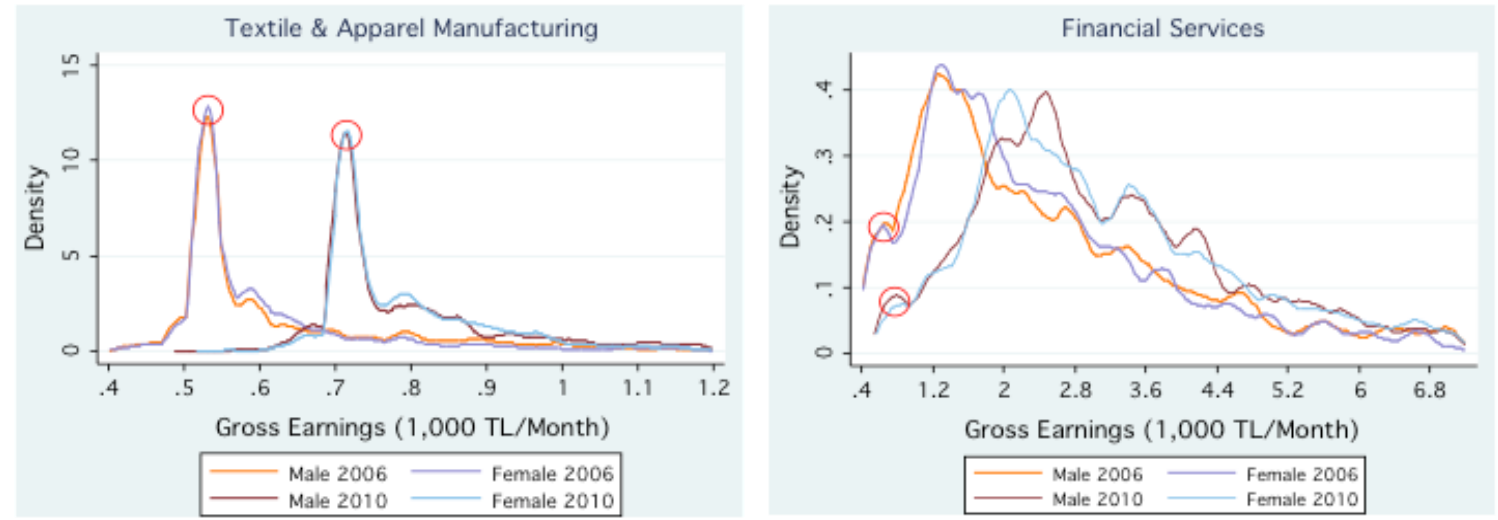

*Circles in the graphs horizontally correspond to minimum wage. 


\section{A5 Gender Gap In EARnings: Regression Analysis}

A set of specifications of the form:

$$
\text { HourlyEarning } \$_{f}=\beta_{0}+\beta_{1} \text { Female }_{i f}+\varepsilon_{i f}
$$

run with alternating fixed effect dummies in each specification. $i$ represents employee, $f$ firm, Female takes 1 if employee is female and 0 if male. Number of categories within each variable is as follows: Sub-Sector: 25 for both years, Occupation: 26 for 2006 and 38 for 2010, Education: 5 for both years, Firm: 18K for 2006 and 14K for 2010.

Table A5.1a: Results of Specification A5.1 for All Sectors*

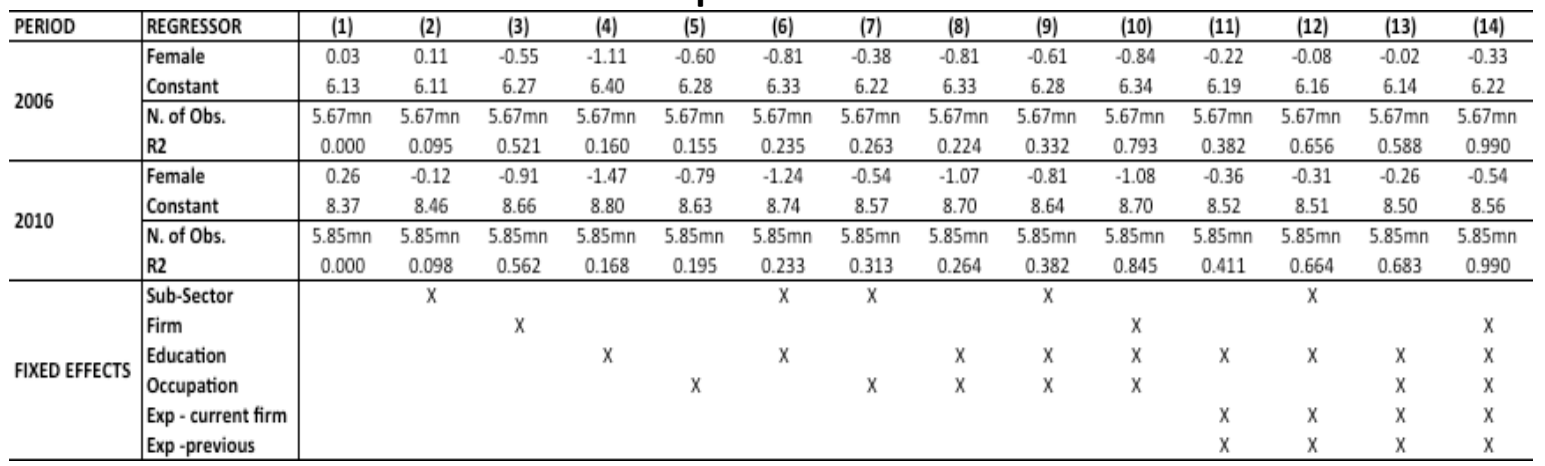

*All coefficients significant at 1\%; Fixed Effects variables are in multiplicative form

Table A5.1b: Results of Specification A5.1 for Manufacturing*

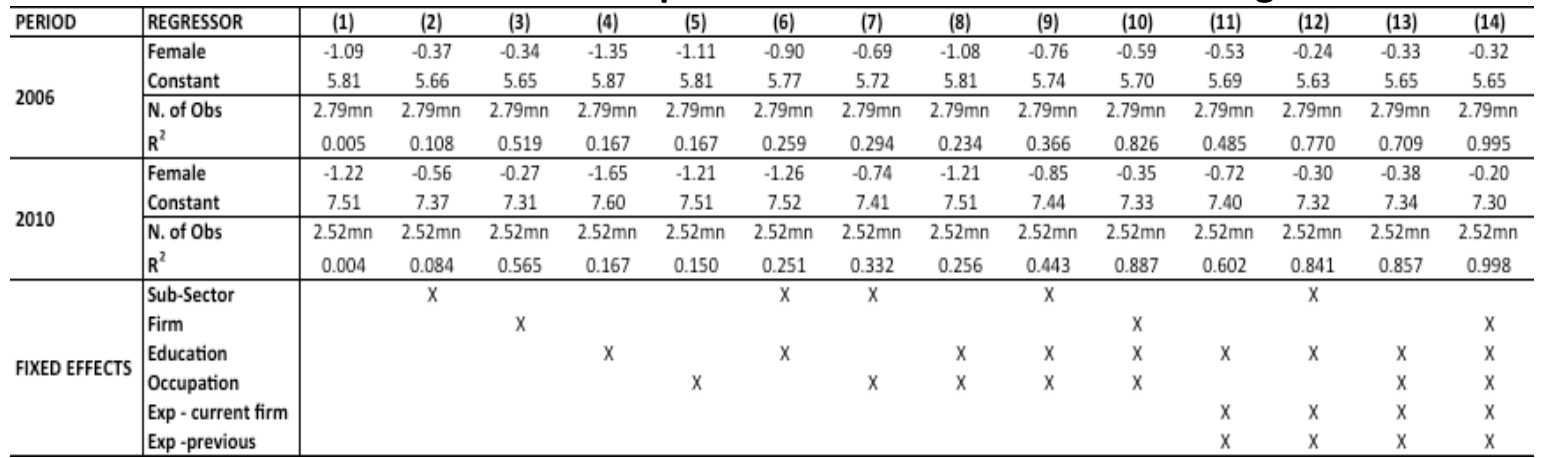

*All coefficients significant at 1\%; Fixed Effects variables are in multiplicative form

Table A5.1c: Results of Specification A5.1 for Services*

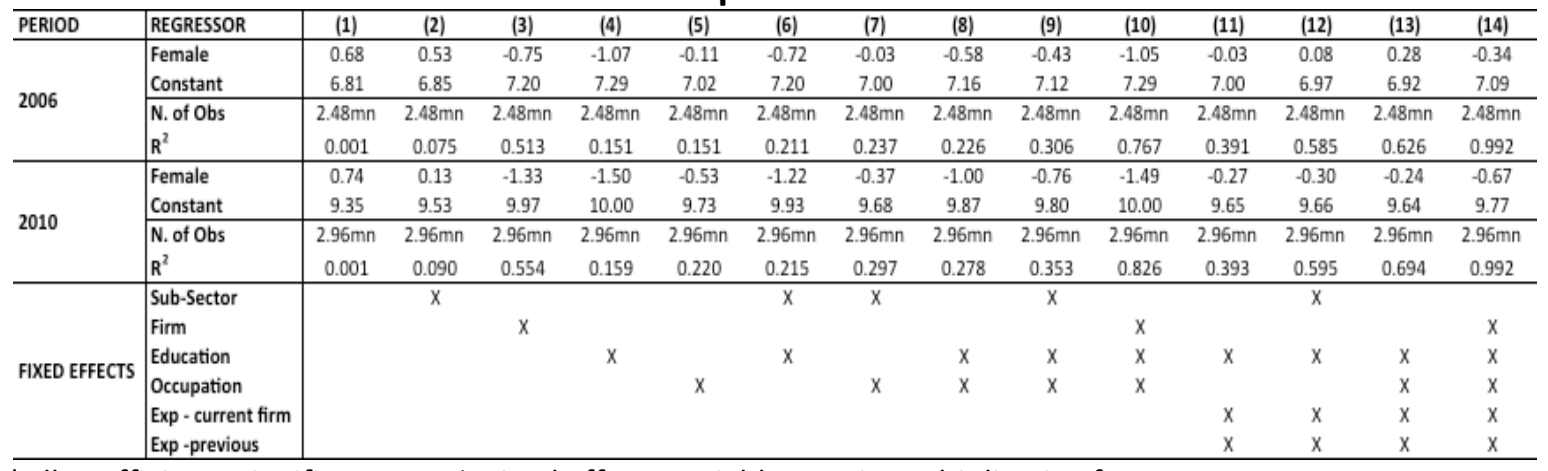

*All coefficients significant at 1\%; Fixed Effects variables are in multiplicative form 
Gender Earnings Gap in the Formal Labor Market in Turkey

HourlyEarning $s_{f f}=\beta_{0}+\beta_{1}$ Female $_{\text {if }}+\beta_{2} \operatorname{ExpA}_{\text {if }}+\beta_{3} \operatorname{ExpB}_{\text {if }}+\beta_{4}$ Educ $_{\text {if }}+\beta_{5}$ Female $_{i f}{ }^{*}$ Educ $_{\text {if }}+\varepsilon_{\text {if }}$

ExpA is the number of years that employee has been working in the current firm and ExpB shows the previous work experience in years. Education is the dummy showing the educational attainment of an employee.

Table A5.2: Results of Specification A5.2*

\begin{tabular}{|c|c|c|c|c|c|c|}
\hline \multirow{2}{*}{ REGRESSOR } & \multicolumn{3}{|c|}{2006} & \multicolumn{3}{|c|}{2010} \\
\hline & (1) & (2) & (3) & (1) & (2) & (3) \\
\hline Female & -0.48 & -0.11 & -0.21 & -0.48 & -0.11 & -0.14 \\
\hline Middle & 0.88 & 0.66 & 0.10 & 1.61 & 1.15 & 0.45 \\
\hline High & 2.05 & 1.47 & 0.71 & 3.07 & 2.09 & 0.97 \\
\hline Vocational & 3.19 & 2.47 & 0.64 & 4.07 & 3.33 & 1.39 \\
\hline Higher & 9.71 & 8.40 & 4.98 & 12.90 & 11.10 & 6.16 \\
\hline Middle*Female & 0.82 & 0.47 & 0.13 & 0.54 & 0.32 & 0.16 \\
\hline High*Female & 0.96 & 0.58 & 0.05 & 0.93 & 0.56 & 0.25 \\
\hline Vocational*Female & 0.21 & 0.03 & 0.28 & 0.53 & 0.10 & 0.51 \\
\hline Higher ${ }^{*}$ Female & -0.57 & -0.80 & -1.05 & -0.93 & -1.29 & -1.38 \\
\hline Constant & 3.35 & 3.83 & 5.04 & 4.15 & 4.94 & 6.70 \\
\hline N. of Obs. & $5.67 \mathrm{mn}$ & $5.67 \mathrm{mn}$ & $5.67 \mathrm{mn}$ & $5.85 \mathrm{mn}$ & $5.85 \mathrm{mn}$ & $5.85 \mathrm{mn}$ \\
\hline $\mathrm{R}^{2}$ & 0.29 & 0.48 & 0.97 & 0.32 & 0.50 & 0.98 \\
\hline \multirow{3}{*}{ Fixed Effects } & $\operatorname{Exp} A^{*}$ & $\operatorname{Exp} A^{*}$ & $\operatorname{ExpA} A^{*}$ & $\operatorname{ExpA*}$ & ExpA* & ExpA* \\
\hline & ExpB & $\operatorname{ExpB}^{*}$ & $\operatorname{Exp}^{*}$ & ExpB & ExpB* & ExpB* \\
\hline & & Sub-Sector & Firm & & Sub-Sector & Firm \\
\hline
\end{tabular}

*All coefficients significant at $1 \%$.

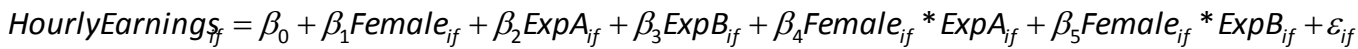

Table A5.3: Results of Specification A5.3*

\begin{tabular}{l|ccc|ccc}
\hline \multirow{2}{*}{ REGRESSOR } & \multicolumn{3}{|c}{$\mathbf{2 0 0 6}$} & \multicolumn{3}{c}{$\mathbf{2 0 1 0}$} \\
\cline { 2 - 7 } & $\mathbf{( 1 )}$ & $\mathbf{( 2 )}$ & $\mathbf{( 3 )}$ & $\mathbf{( 1 )}$ & $\mathbf{( 2 )}$ & $\mathbf{( 3 )}$ \\
\hline Female & -0.94 & -0.86 & -1.20 & -1.46 & -1.60 & -1.76 \\
ExpA & 0.47 & 0.43 & 0.32 & 0.61 & 0.57 & 0.49 \\
ExpA*Female & 0.03 & 0.02 & 0.01 & 0.11 & 0.08 & 0.01 \\
ExpB & 0.09 & 0.10 & 0.11 & 0.14 & 0.15 & 0.16 \\
ExpB*Female & 0.03 & 0.03 & 0.03 & 0.04 & 0.06 & 0.05 \\
Constant & 3.27 & 3.36 & 3.71 & 4.40 & 4.45 & 4.71 \\
\hline N. of Obs. & $5.67 \mathrm{mn}$ & $5.67 \mathrm{mn}$ & $5.67 \mathrm{mn}$ & $5.85 \mathrm{mn}$ & $5.85 \mathrm{mn}$ & $5.85 \mathrm{mn}$ \\
$\mathrm{R}^{2}$ & 0.26 & 0.31 & 0.64 & 0.28 & 0.32 & 0.67 \\
\hline \multirow{2}{*}{ Fixed Effects } & Educ & Educ* & Educ* & Educ & Educ* & Educ $^{*}$ \\
& & Sub-Sector & Firm & & Sub-Sector & Firm $^{*}$ \\
\hline
\end{tabular}

*All coefficients significant at $1 \%$. 